\title{
Thermal Surface Analysis on Modern Apartment's Façade in Penang, Malaysia
}

\author{
Yasser Arab ${ }^{1}$, Ahmad Sanusi Hassan ${ }^{1}$ and Bushra Qanaa ${ }^{2}$ \\ ${ }^{1}$ School of Housing, Building, and Planning. Universiti Sains Malaysia \\ ${ }^{2}$ Faculty of Architecture, Ittihad Private University, Malaysia
}

\begin{abstract}
This research discusses the thermal surface performance of the west façade of two high-rise apartments in Penang, Malaysia. The scope of this study is to compare results of two selected case studies. The modern architectural style was a popular style in the 1970s to 1990s, the style is applied basic geometric design without many expressions of the cultural identity known as an internationalized style. Two selected case studies are high-rise apartment buildings in Penang Island. The first case study is Halaman Kristal Apartment which has twenty-one stories located in Lengkok Free School. The second case study is Apartment Mutiara Idaman 1, the twenty-one stories building located in Solok Tengku, Jelutong. Thermal imager camera device named Fluke Ti20 was used to snap for the thermal image to the west façade surface of the two selected case studies. The thermal images were taken every hour from 12:00 to 6:00 pm on 16th June 2017. The results show that both cases studies had high surface temperature during the evening hours. Basic geometric design without the use of balconies in the design causes negative effects to the façade thermal performance.
\end{abstract}

Keywords: apartment facade; passive design; modern style; thermal image

\section{Introduction}

Based on a study of the Malaysian statistics department, residential high-rise buildings are considered as the main aspect of the residential buildings with about $20 \%$ of the total residential buildings number (Figure1), the study shows that in 2010 more than 2 million high-rise buildings are used for residential purposes and this number is increasing fast during the last 2 decades in order to provide the huge demand of units for people who migrate from rural to urban areas [1]. Thus, this study examines the thermal performance of two high-rise building's façade with modern architectural style to study the efficiency of the building's facades design of the modern style. Penang Island which is considered as the second most important state in Malaysia was selected for this study with two if high-rose buildings on the eastern coast of the island, the island overall has been under huge development for the last 3 decades, and the first high-rise building in the Penang was constructed in the 1960s [2,3].

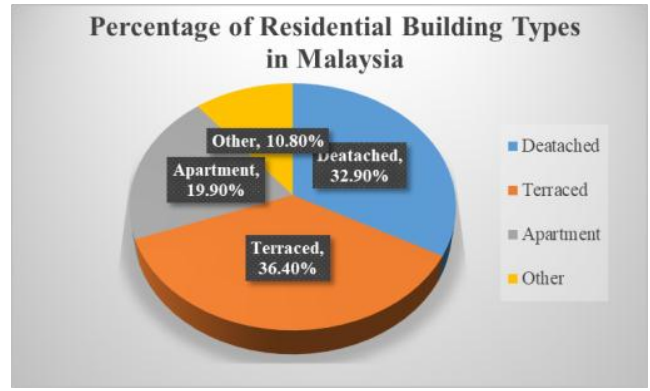

Fig. 1: The residential building types percentage in Malaysia 
In order to design in a tropical country like Malaysia, a good and efficient façade design should be provided by having an excellent, sufficient, and suitable shading device which will help to minimize the unnecessary sunlight penetration to penetrate into the house and increase the façade shading area which will lead to decrease the exposure to the direct sunlight $[4,5]$. Exposing to the direct sunlight causes heat transfer problem from the external façade walls into the indoor atmosphere [6-9], as results; it produces an uncomfortable condition because of increasing of the temperature which is the reason of an extra usage of air-conditioning to regain the required thermal comfortable [10].

\section{Case Studies}

As mentioned earlier, two of the high-rise buildings in Penang island, Malaysia were selected to measure the façade surface temperature. The first selected building is Halaman Kristal 2 Apartment located in Lengkok Free School, Jelutong (Figure 2). On the other hand, the second selected case study is Mutiara Idaman 1 located in Solok Tengku, Jelutong. Both cases studies were built to accommodate low-income families.

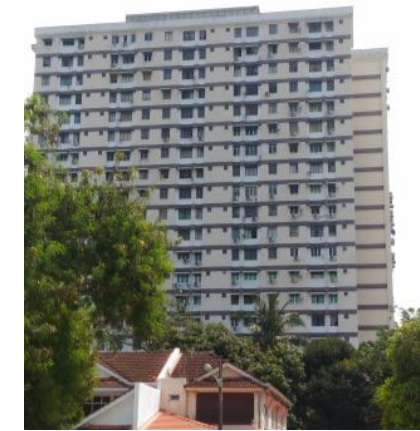

Fig. 2: Halaman Kristal 2 Apartment

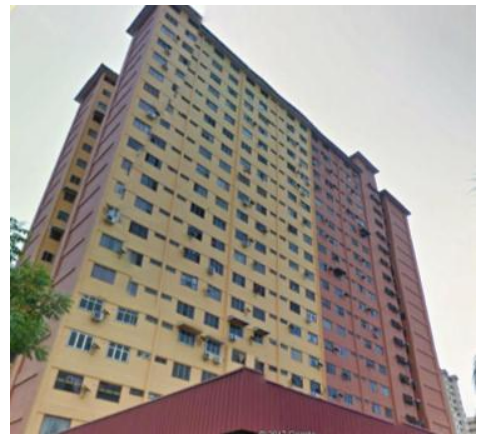

Fig. 3: Mutiara Idaman 1

\section{Methodology}

In order to examine the performance of the façade surface thermal imager Fluke Ti20 were used to snap thermal images of the west façade of both selected case studies on June 16'2017, hourly from 12:00 to 6:00 P.M. [11]. As shown in Figure 4 The Date June 16 was selected to snap the thermal images based on the graph of the annual maximum and minimum temperature in Penang (Figure 4) which shows that the highest temperature in Penang recorded in March [12].

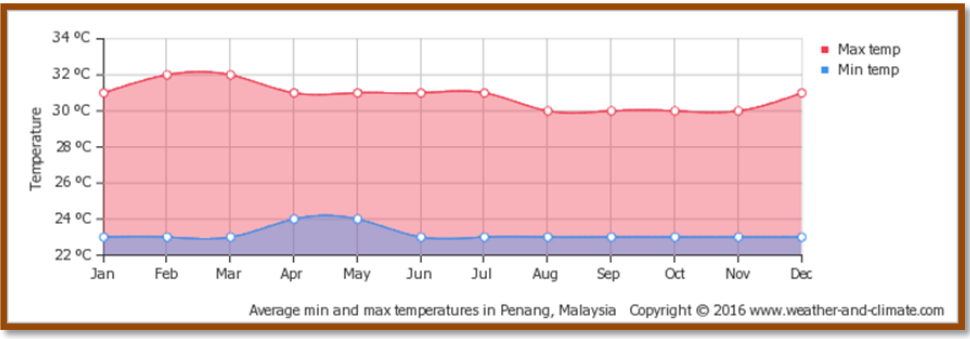

Fig. 4: The average minimum and maximum annual temperature in Penang, Malaysia

The infrared camera called Fluke Ti20 thermal imager (Figure 5) was used to take the façade thermal images of the case studies, which gives thermal façade image with all thermal information and the surface temperature of each point of the grid of the faced. After snapping the façade thermal images by Fluke Ti20, all images were imported into SmartView ${ }^{\circledR}$ computer software. The software produces digital and infrared images to help the researched reading the thermal images information as shown in Figure $6[13,14]$. 


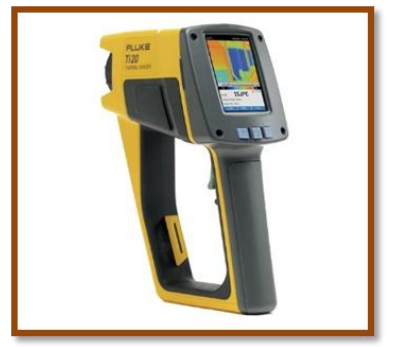

Fig. 5: Fluke Ti20 thermal imager

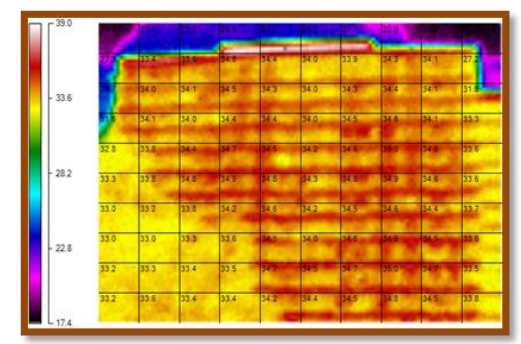

Fig. 6: An example of an infrared image

\section{Results Analysis}

The research has two limitations while snapping the thermal images. The first one is the distance between the selected case studies, which caused about 10 minutes delay when taking the façade thermal images, while the second limitation is that the study is limited only to the afternoon and evening hours from 12:00 to 6:00 PM and that because the sunlight during these hours is more intense and cause more effect than the morning hours. In addition, there is a slight difference in the orientation of both buildings [15].
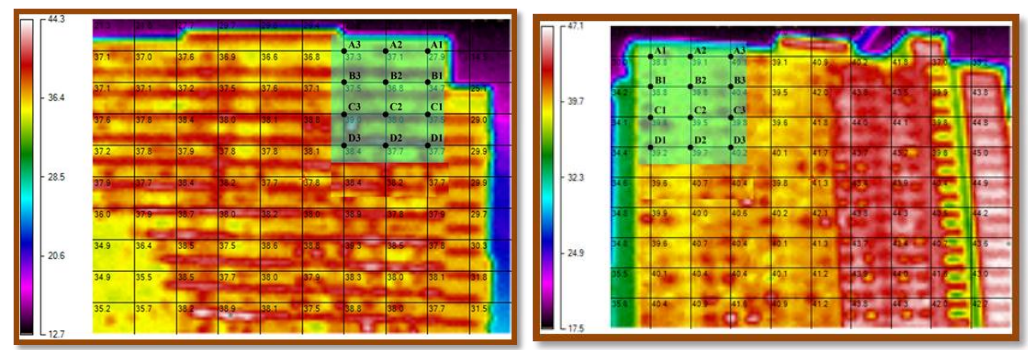

Fig. 7: The Selected Points of Both Case Studies.

The façade thermal images of Halaman Kristal 2 and Mutiara Idaman 1 were captured on 15th March 2017 from 12:00 to 6:00 pm. Figure 7 displays the selected points of each case study façade, and Table 1 shows the thermal images of the selected case studies. The surface temperature of the selected points is shown in Tables 2 and 3, while Tables 4 and 5 show the average surface temperature of Halaman Kristal 2 and Mutiara Idaman 1.

TABLE I: The Thermal Images of the Two Case Studies.

\begin{tabular}{|c|c|c|}
\hline Time & Halaman Kristal 2 & Mutiara Idaman 1 \\
\hline $12: 00$ & 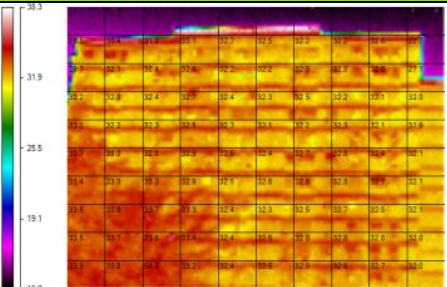 & $=$ \\
\hline $1: 00$ & 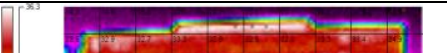 & 5 \\
\hline
\end{tabular}




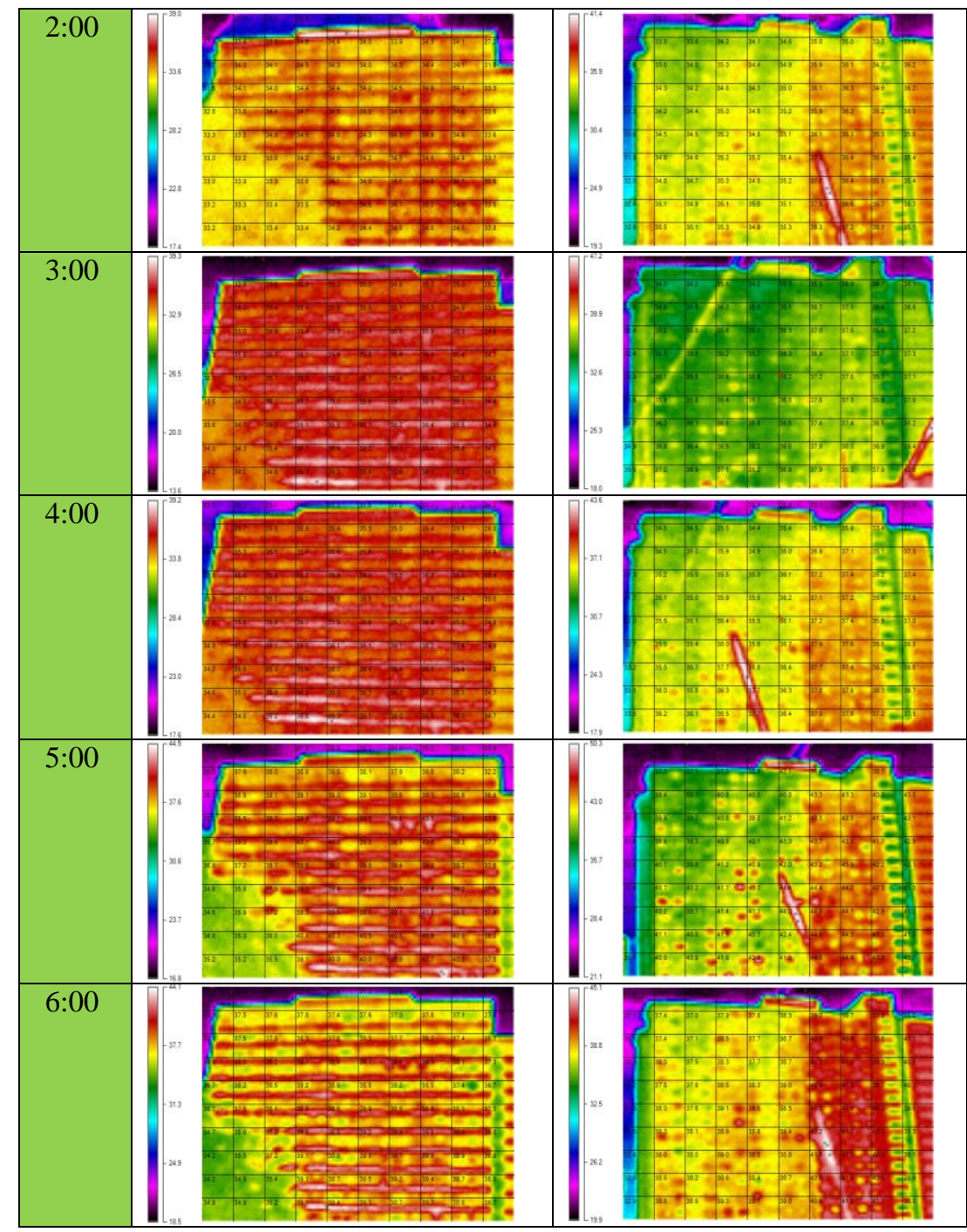

TABLE II: The Surface Temperature of Halaman Kristal 1 West Façade Selected Points.

\begin{tabular}{|c|c|c|c|c|c|c|c|c|c|c|c|c|c|c|}
\hline \multirow{8}{*}{ 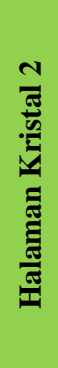 } & \multirow{8}{*}{$\frac{10}{\frac{1}{0}}$} & $\begin{array}{l}\text { Reint } \\
\text { Time }\end{array}$ & A1 & A2 & A3 & B1 & B2 & B3 & C1 & $\mathrm{C2}$ & C3 & D1 & D2 & D3 \\
\hline & & 12:00 & 32.6 & 32.2 & 32.2 & 32.6 & 32.8 & 32.5 & 52.1 & 32.2 & 32.5 & 32.1 & 32.3 & 32.2 \\
\hline & & $1: 00$ & 33.4 & 33.3 & 32.8 & 32.9 & 33 & 33 & 32.4 & 32.8 & 32.9 & 3 & 33.3 & 33.1 \\
\hline & & $2: 00$ & 34.1 & 34.3 & 33.9 & 34.1 & 34.4 & 34.3 & 34 & 34.6 & 34.5 & 34 & 35 & 34.6 \\
\hline & & 3:00 & 35 & 35.3 & 34.9 & 34.9 & 35.3 & 35.1 & 35.3 & 35.9 & 35.8 & 35.4 & 36 & 35.9 \\
\hline & & $4: 00$ & 35.1 & 35.4 & 35 & 35 & 35.4 & 35.2 & 35.6 & 36.3 & 36.3 & 35.4 & 35.8 & 35.7 \\
\hline & & $5: 00$ & 38.2 & 38.6 & 37.9 & 38.6 & 39.1 & 38.8 & 39.1 & 40.3 & 40.4 & 39.3 & 40 & 39.5 \\
\hline & & 6:00 & 37.1 & 37.8 & 37 & 37.4 & 38.2 & 37.7 & 38.1 & 39.5 & 39.4 & 37.4 & 38.5 & 38.2 \\
\hline
\end{tabular}

TABLE III: The Surface Temperature of Mutiara Idaman 2 West Façade Selected Points.

\begin{tabular}{|c|c|c|c|c|c|c|c|c|c|c|c|c|c|c|}
\hline \multirow{8}{*}{ 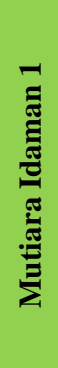 } & \multirow{8}{*}{ 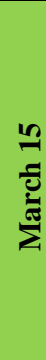 } & $\begin{array}{l}\text { Reint } \\
\text { Time }\end{array}$ & A1 & A2 & A3 & B1 & B2 & B3 & C1 & $\mathrm{C} 2$ & C3 & D1 & D2 & D3 \\
\hline & & 12:00 & 31.7 & 32.2 & 32.8 & 31.8 & 32.7 & 32.7 & 32.2 & 32.9 & 32.3 & 32.6 & 32.2 & 32.4 \\
\hline & & $1: 00$ & 32.3 & 32.3 & 34 & 32.6 & 32.5 & 34 & 32.8 & 33.6 & 32.9 & 32.6 & 33 & 33 \\
\hline & & 2:00 & 33.8 & 33.6 & 34.2 & 33.8 & 34 & 35 & 34.3 & 34.2 & 34.8 & 34.2 & 34.4 & 35 \\
\hline & & $3: 00$ & 34.5 & 34.2 & 35.6 & 34.8 & 35.8 & 36.3 & 35.2 & 35.8 & 35.6 & 35.3 & 35.5 & 36.2 \\
\hline & & $4: 00$ & 34.5 & 34.5 & 35 & 34.5 & 35 & 35.5 & 35.2 & 35 & 35.5 & 35.1 & 35 & 35.9 \\
\hline & & $5: 00$ & 37.7 & 37.1 & 37.3 & 39.4 & 38.7 & 40.8 & 39.9 & 39.2 & 40.8 & 39.6 & 39.3 & 40.8 \\
\hline & & $6: 00$ & 37.4 & 37 & 37.9 & 37.4 & 37.1 & 38.5 & 38 & 37.5 & 38.3 & 37.8 & 37.6 & 38.5 \\
\hline
\end{tabular}


TABLE IV: The Average of Halaman Kristal 2 Surface Selected Point's Temperature.

\begin{tabular}{|c|c|c|c|c|c|c|c|}
\hline \multirow{8}{*}{ 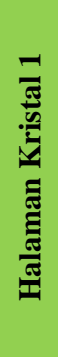 } & \multirow{8}{*}{ 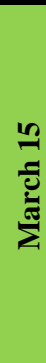 } & $\begin{array}{l}\text { Point } \\
\text { Time }\end{array}$ & A & B & C & D & Average \\
\hline & & 12:00 & 32.33 & 32.63 & 32.27 & 32.20 & 32.63 \\
\hline & & 1:00 & 33.17 & 32.97 & 32.70 & 33.13 & 33.23 \\
\hline & & 2:00 & 34.10 & 34.27 & 34.40 & 34.73 & 34.77 \\
\hline & & 3:00 & 35.07 & 35.10 & 35.67 & 35.77 & 35.63 \\
\hline & & 4:00 & 35.17 & 35.20 & 36.07 & 35.63 & 35.77 \\
\hline & & 5:00 & 38.23 & 38.83 & 39.93 & 39.60 & 39.50 \\
\hline & & $6: 00$ & 37.30 & 37.77 & 39.00 & 38.03 & 38.40 \\
\hline
\end{tabular}

TABLE V: The Average of Mutiara Idaman 1 Surface Selected Point's Temperature.

\begin{tabular}{|c|c|c|c|c|c|c|c|}
\hline \multirow{8}{*}{ 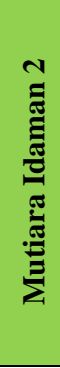 } & \multirow{8}{*}{ 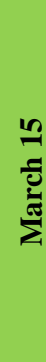 } & Time & $\mathbf{A}$ & B & C & D & Average \\
\hline & & 12:00 & 32.23 & 32.40 & 32.47 & 32.40 & 32.60 \\
\hline & & 1:00 & 32.87 & 33.03 & 33.10 & 32.97 & 33.13 \\
\hline & & 2:00 & 33.87 & 34.27 & 34.43 & 34.53 & 34.73 \\
\hline & & 3:00 & 34.77 & 35.63 & 35.53 & 35.67 & 36.07 \\
\hline & & 4:00 & 34.67 & 35.00 & 35.23 & 35.33 & 35.67 \\
\hline & & $5: 00$ & 37.37 & 39.63 & 39.97 & 39.90 & 40.37 \\
\hline & & 6:00 & 37.43 & 37.67 & 37.93 & 37.97 & 38.23 \\
\hline
\end{tabular}

\section{Discussion}

Figure 8 shows the average of façade surface temperature for Halaman Kristal 1 and Mutiara Idaman 2, the results show:

- Both cases studies have very close surface temperature at all measurements hours.

- The lowest façade surface temperature of Halaman Kristal 2 building was recorded at 12:00 PM with $32.63{ }^{\circ} \mathrm{C}$.

- The highest temperature in an average of Halaman Kristal 2 was $39.50{ }^{\circ} \mathrm{C}$ at 5:00 PM.

- The lowest surface temperature of Mutiara Idaman 1 was recorded at 12:00 PM with $32.60^{\circ} \mathrm{C}$.

- The highest temperature of Mutiara Idaman 1 was at 5:00 PM with $40.37^{\circ} \mathrm{C}$.

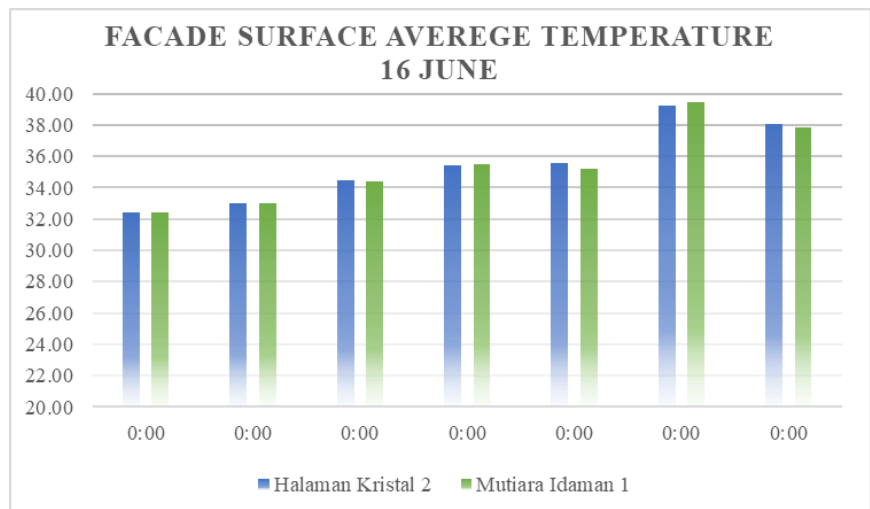

Fig. 8: The Average surface temperature of both case studies

\section{Conclusion}

The surface thermal images results show that both case studies' façade have similar surface temperature and same performance during all simulation hours. The results find that the modern architectural style's façade is not very sufficient in term of façade thermal performance, the lack of shading devices and the building orientation left a negative effect on the façade thermal performance. Thus, the modern architectural style faced design left a 
bad effect on the indoor temperature which causes uncomfortable atmosphere and increases the usage of air conditioning in order to reach the indoor thermal comfort level. And that will maximize the energy consumption. The research recommends applying the same study on other high-rise buildings with different architectural style and compare between the façade thermal performance of them and try to provide guideline for better façade shading design

\section{Acknowledgment}

The authors would like to express appreciation for the financial support under Fundamental Research Grant scheme by Universiti Sains Malaysia.

\section{References}

[1] Malaysia, D. O. (2010). Characteristics of Living Quarters 2010. Putrajaya: Department of Statistics Malaysia.

[2] Hoffman, A. V. (1996). High ambitions: The past and future of American low- income housing policy. Housing Policy Debate, 7(3), 423-446.

[3] Y. Arab, A. S. Hassan, and B. Qanaa. "Thermal surface analysis on high-rise building façades with neo-minimalist and modern style in Penang, Malaysia." AIP Conference Proceedings. Vol. 1892. No. 1. AIP Publishing, 2017.

[4] M. S. Bakhlah and A. S. Hassan, "The study of air temperature when the sun path direction to ka'abah: with a case study of Al-Malik Khalid Mosque, Malaysia", International Transaction Journal of Engineering, Management \& Applied Sciences \& Technologies, pp. 185-202, 2012.

[5] Yasser Arab. "Facade Design Efficiency on Extent Sunlight Penetration in Neo-Minimalist Style Apartments in Penang, Malaysia”, Journal of Architectural Engineering Technology, Vol. 4(2) 2015.

[6] A. S. Hassan and M. Ramli, "Natural ventilation of indoor air temperature: A case study of the Traditional Malay House in Penang", American Journal of Engineering and Applied Sciences, pp. 521-528, 2010.

[7] H. Feriadi and N. H. Wong, "Thermal comfort for naturally ventilated houses in Indonesia", Energy and Buildings, pp. 614-626, 2004.

[8] Royle, K., \& Terry, C. (1990). Hawaiian Design: Strategies for Energy Efficient Architecture. Collingdale, Honolulus: DIANE Publishing.

[9] Rahman, A. M. (1995). Housing design in relation to environmental comfort: A comparison of the traditional Malay house and modern housing including work in the tripartite programme between Universiti Sains Malaysia, the Welsh School of Architecture and the UK building research. Building research and information, 23(1), 49-54.

[10] K. M. Al-Obaidi, M. Ismail and A. M. A. Rahman, "A review of the potential of attic ventilation by passive and active turbine ventilators in tropical Malaysia", Sustainable Cities and Society, Vol.10, pp. 232-240, 2014.

[11] A. S. Hassan, Yasser Arab. Thermal Façade Surface Study on Early Modern Apartment in Kuala Lumpur. Vol 2, pp 168-174. 2017.

[12] Weather and climate. (2016). Retrieved from weather and climate: www.weather-and-climate.com

[13] Bezbabicheva, O. I., Bilchenko, A. V. and Kyslov, A. H. "Forecasting of Temperature Tension in Facade Beams of Bridge Constructions". Science and Transport Progress. Bulletin of Dnipropetrovsk National University of Railway Transport, (33), PP 28-31, 2010.

[14] Y. Arab, A. S. Hassan, and B. Qanaa. "Comparative Study of Thermal Surface Analysis on High-Rise Apartment Facades with Colonial and Neo-Minimalist Style Design in Penang, Malaysia." Advanced Science Letters23.7 (2017): 6148-6152.

[15] A. S. Hassan, Yasser Arab. "Thermal Surface Analysis on Colonial Style's Apartment Facades in Putrajaya, Malaysia." Advanced Science Letters 23.7 (2017): 6144-6147. 